\title{
A Critique of Uffelmann's German Translation of Soyinka's Aké Years of Childhood: Closing the Missing Gap
}

\author{
Ezekiel O. OLAGUNJU \\ Department of Foreign Languages \\ Obafemi Awolowo University \\ Nigeria \\ Akintoye S. JAPHET \\ Department of Linguistics and Communication Studies \\ Osun State University \\ Nigeria
}

\begin{abstract}
Uffelmann's Aké, Jahre der Kindheit is a German translation of Soyinka'sAké Years of Childhood. Uffelmann's translation demonstrated a high degree of faithfulness to the source text as can be accessed by a native speaker of English. However, it failed to reproduce some prominent Soyinka's styles rooted in his mother tongue, Yoruba. The paper therefore identified the hidden Yoruba styles in the source text with the aim to providing better German equivalence of the author's original intention. Using Nida's dynamic equivalence, Aké, Jahre der Kindheit and Aké Years of Childhood were closely studied with competence in the language of the source text, (English), the language of the target text, and the language of the prevailing styles in the source text (Yoruba). The paper recommends that the translation of Soyinka's work of a similar style will require competence in the three languages.
\end{abstract}

Keywords: Translation styles, Equivalence, Cultural Backgrounds, Code Switching, Code Mixing.

\section{Introduction}

Wole Soyinka was born on July 13, 1934 in Abeokuta, Southwest Nigeria. Right from childhood, Wole received western education from his father, who is deeply rooted in the Christian faith. He was also greatly influenced by the traditions and myths of his Yoruba folks. In the 1950s, he studied English Literature in the Great Britain.

When he returned to his native country, he engaged himself with African drama. In his works, Soyinka associates the western and African traditions with a strong political involvement. Despite his bi-culturality, he often uses English language. What distinguishes him is his virtuous and hardly understandable combination of different cultural traditions. He has the desire to bring his Africa homeland and the western culture to a round-table dialogue.

Aké, Years of Childhood is one of the most famous books by Wole Soyinka. It is an autobiography, in which Soyinka describes the first eleven years of his life with great flashback and much humor. He talks of his place of birth, Aké, a missionary station in Nigeria.

Soyinka had an eventful childhood in Aké, where his father was the headmaster of a local primary school. His father was a noble educated man whose house served as the brook of intellect for Aké and its environs. He talks of his love for his mother, whom he calls wild Christian, because in a way, she was a passionate Christian but in another way, a deep African hypocrite. He also talks of the division that characterizes the Christian and the African tradition as well as his grandfather's rituals. Soyinka's versatility in religion and culture leaves indelible marks on his works. The text begins with a sharp description of his hometown and ends with the throwing of atomic bomb on Hiroshima and Nagasaki - and the prospect of the first pair of shoes.

As a matter of fact, literature in Africa is a showcase of styles. Its hybrid nature is birthed by its content (the world being represented) and forms (the style and manner of expression). It is typically African and built after European model. In this work, we will concentrate on this hybrid characteristic of Wole Soyinka's Aké, Years of Childhood which are not represented in the German translation Aké, Jahre der Kindheit by Inge Uffelmann. 
This paper seeks to examine Nida's principle of equivalence in Inge Uffelmann's Aké, Jahre der Kindheit, the German's translation of Wole Soyinka's Aké, Years of Childhood. This research should unveil on one hand, the difficulties in translating Yoruba-specific styles in the source text, and on the other hand suggests ways by which these problems can be solved.Thepaper is divided into three parts. The first part deals with the theoretical approaches to language, culture and translation. The second part concentrates on the strategies used in the translation of culture-specific elements. The third part entails the assessment of the translation work of Inge Uffelman. In the analysis, the following conventions are used:

$\begin{array}{ll}\text { NPE } & \text { Nigerian Pidgin English } \\ \text { PEE } & \text { Preferred English Expression } \\ \text { PGT } & \text { Proper German Translation } \\ \text { ST } & \text { Source text } \\ \text { TT } & \text { Translated text } \\ \text { SYC } & \text { Soyinka Yoruba Code mixing/ switching } \\ \text { SYT } & \text { Soyinka's Yoruba Transliteration } \\ \text { UGT } & \text { Uffelmann German Translation } \\ \text { YBT } & \text { Yoruba background to the source text } \\ \text { YCM } & \text { Yoruba code mixing } \\ \text { YOR } & \text { Yoruba Mother tongue background }\end{array}$

\section{The high side of the Inge Uffelmann's translation of Aké}

This study shows that Inge Uffelmann has made commendable efforts in translating the text Aké, Years of Childhood into German asAké, Jahre der Kindheit. In content and style, one can say that the translation by Inge Uffelmann is almost like the original work. First, it provides German translations of the glossaries in the original text, making the information available to German readers. For example: oja agba $(\mathrm{ST}=169 / \mathrm{TT}=242$ ). Second, it also provides a commendable translation of the expressions in Nigerian Pidgin. Soyinka did not only use Yoruba in the source text, he also used the Nigerian Pidgin. The Nigerian Pidgin English is one of the realities in the Nigerian linguistic wealth deriving $80 \%$ of its lexicons from English and the remaining 20\% from local languages (Olagunju, 2003:50). An instance of Uffelmann's translation of NPE into German is given below:

Nigerian Pidgin English (NPE):

'Look am master, a no be lie. Look genuine 'morocco' leather. E fit you, big man like you must have leather brief-case for carry file. E be genuine. Put am one more shirt or toresa" (ST=48).

Gastarbeiterdeutsch/Gebrochenedeutsche Sprache (GDS) Broken German:

"Hier Sie sehen, ich nix lügen. Guck, guck hier, original Marokko-Leder. Prima für sie. Boß wie Sie brauchen Ledertasche für Akten. Ist echt! Gib noch ein Hemd, oder noch Hose" (TT = 94).

In Uffelmann's effort to translate NPE into German, he translated the local "Pidgin English" into broken German, although this does not reflect the sense of the local (pictorial) language favourably where NPE serves as the only means of communication for the populace of many languages and is even spoken by the educated stratum in informal gatherings. The attempt of Uffelmann to find a close equivalence is, however, commendable.

\section{Coping with Soyinka's stylistic code mixing with Yoruba}

Code switching and code mixing are realities in the African society where most of the people speak three languages - mother tongue, official language and the dialect of their regions. In attempts to reproduce the multilingual African society, African writers though using European languages, will still have to produce instances of code switching and code mixing being the linguistic reality of the region. This is actually the case in Soyinka's Aké. Translating a text involving such code mixing expressions becomes a great task for the translator. In Uffelmann's Aké, Jahre der Kindheit, the untranslated Yoruba conversations and songs are retained in the translation as they are in the source text. Therefore, the readers of the target text have no idea of what those words can mean. Some examples are:

1(a) Jesu, Jesu gbami $(\mathrm{ST}=190 / \mathrm{TT}=273)$

Jesus, Jesus, deliver me

(b) fi grammar re l'epa, o gbe fun $(\mathrm{ST}=211 / \mathrm{TT}=303)$ use words to disorient him

(c) Muпти (ST = 191/TT = 274)Fool 
This stylistic code carries a great set back to the German translation since it falsely prevent translation of some words that are better translated into German than being loaned. That is the case with gongo in (2) below.

2(a) Now the matter has reached gongo (Soyinka = Pg. 208)

(b) Jetzt hat die Angelegenheit gongo erreicht $(\mathrm{TT}=$ Pg. 298)

(c) Ọ̀ọ̀ náà ti dé góńgó.

Word def. perf. reach peak

'The matter has got to its peak'

The use of góngó instead of peak in SYC occurs as a literary style employing deliberate code switching between English and Yoruba. Soyinka who had also translated into English some Yoruba novels could not have been ignorant of the English equivalent of gongo. Usually other Yoruba-English bilinguals and perhaps some other Nigerians who are familiar with Yoruba should be aware of this stylistic code mixing. So, 'the matter has reached gongo' is not a big problem for a bilingual that is competent in both languages. However, there is no evidence that the German translator has this Yoruba-English bilingual background.Therefore,the Yoruba code is locked out of the translation. The UGT simply takesgóngó as a proper noun just like a personal name that does not require any translation. Then the German readers may never realise the lexical input of gongo in the text. See how data in 2(b) is revised in 3(b) in line with the underlying Yoruba version in 2 (c).

3(a) ?Jetzt hat die Angelegenheit gongo erreicht
now perf. def. matter
'Now, the matter has got to its góngó'
(b) Jetzt hat die Angelegenheit den höchsten Punkt erreicht
now perf. def. matter
'Now, the matter has got to its peak'

The translation is further illustrated in diagram (4).

\section{The problems of Soyinka's poetic Transliteration style}

Following Newmark (1981),Soyinka does word for word translation (into English) of certain Yoruba words/expressions. This style reveals that Soyinka developed the story from his Yoruba background directly transliterating some structures from Yoruba as can be seen in 5(c).

5(a) $\quad$...on the faces of the guest (ST = Pg. 29)

(b) ...auf den Gesichtern der Gäste (TT pg. 47, 188)

in the faceof the guests

(c) ni ojú àwọn àlejò

in face $3 \mathrm{pl}$ guest

'while the guest are still around'

(d) in Anwesenheit der Gäste

in the presence of the guests

On the faces of the guest (ST = Pg. 29)in 5(a) improperly translated as ...auf den Gesichtern der Gästein 5(b) should have been translated as in the presence of the guestsas evident in the underlying Yoruba strings in5(c) which has to be rendered in German as in 5(d). However, in gloss of (c) which reveals the choice of face literally translated from the Yoruba word ojú 'face or eye' implies that Soyinka was actually doing Nabokov's kind of translation using an unwritten Yoruba version of his story as the source. As held in Nabokov works, (Nabokov, 1941, 1990, 2011), the ultimate goal in translation is a word-for-word rendition, which obviously ought to respect the cultural and grammatical differences between the languages of the original and target texts. Nabokov's approach is based on three principles. First, translation should be able to provide a free version of the source through paraphrasing. It should clearly show the meaning of the word being basically lexical. Third, it should be literal to both languages. Nabokov gives more credits to multilingualism; however, it requires multi-competence from translators (Rothermel, 2014:136).

7(a) They had come to 'spoil the ground for others (ST = Pg.188)

(b) Sie waren gekommen, um für die anderen Boden zu verderben Pg.298).

(c) wọ́n ba ilẹjẹe

$3 \mathrm{pl}$ spoil-the-ground

'They made things worse' (Literally, they spoilt the ground). 
(d) Sie waren gekommen, um für die anderen das Leben schwerer zu machen.

They perf come round for the others det life difficult to make

'They made things worse for others'

In (9) below, the combination of 'null' and the adjective 'äugig' is quite unconventional in German as used in 9(b). However, Soyinka was able to use 'scoring the round fish eye of zero'in 9(a) in the source textinstead of the expected'scoring zero', because the underlying Yoruba expression produced in 9(c) makes use of ójueja 'eye of a fish'to describeodo 'zero'. Soyinka's use of fish eye is a stylistic transliteration of the Yoruba expression in 9(c). A revision of the translation is provided in 9(d) without making any reference to any fish or its eye. The diagram in (10) shows how 9(b) and 9(d) are linked with the underlying Yoruba form in 9(c).

9(a) All they have been doing is staying away from school and scoring the round fish eye of zero (ST = Pg.183).

(b) *Wenn sie doch in Wahrheit nur geschwänzt haben und keine bessere Note erzielten als eine fischäugige Null $(\mathrm{TT}=$ Pg.263).

(c) Wọ́n gbà òdo olójú ẹja.

3 pl receive null POSS-eye fish

'They scored zero'

(d) Wenn Sie doch in Wahrheit nur geschwänzt haben und keine bessere Note als Null erzielten.

\section{Theoretical implications of Uffelmann's Aké, Jahre der Kindheitin Nida's Dynamic Equivalence}

The responsibility of the translator is in two facets - on the content and then on the style of the source language message (Koller 2011).In this way, one sees the importance of meaning and how it has become the first aspect of translation. Generally, the translations of 1960 to 1970 have the same guidelines. Firstly, the translation changes the expression from one language to another. Secondly, most theorists support the reproduction of the message and its meaning in the target language. Thirdly, the translator has the obligation of finding the nearest equivalence in the target language. In line with this development, Nida \& Taber (1969) have proposed that translation should reproduce the closest natural equivalence of the source language message in the receptor's language considering meaning and style.

The diagram in (11) illustrates Nida's Dynamic equivalence ${ }^{1}$.In the upper row, S stands for source, M1 stands for Message in the source text, R1 stands for receptor of (M1) the message in source text. In the middle row, R stands for receptor who is a translator, $\mathrm{S}$ the translation, which is now serving as a source text for the translation readers; M2 stands for the message of the translated work; R2 stands for receptors of the translated work. In the lowest row, $\mathrm{R}$ and $\mathrm{S}$ represent the critic of the translation who try to assess the level of accuracy of the message in M2 compared with the message in the source. While a translator is not necessarily a R1 (the receptor of M1-source message), a translation critics relays the R1 with R2, in order to establish the dynamic equivalence.

There has been real controversies on the scope of such equivalence between languages in translation (Panou, 2013; Pym, 2010; Munday, 2001; House (1997), Vinay and Darbelnet, 1995; Lefevere (1993, p. 7), Baker (1992), Newmark (1981), Koller (1979), Broeck, 1978; Catford, 1965 and Jakobson,1959).According to Nida (1982), all languages have the same classes of referents: creatures, activities, states, processes, features, relationships. In addition, solidarity and religion characterize every cultural society. The numerous problems between languages can be solved through the specific expressing resources of individual languages. Translation usually proffers various solution to the difference cultural realities. On style, Nida expects the translator to understand stylistic components of the source and target texts taking meaning to be different from style such as pro-form, parataxis, subordination and word choice (Kim 2015:70).

The translation of a europhone-african literature into European languages such as German or French requires more than the language competence of a monolingual source. In the same way, Inge Uffelmann's Aké, Jahre der Kindheit $(A J K)$ also has to cope with the multilingual background of Soyinka's Aké, which combines Yoruba, English and Nigerian Pidgin.

\footnotetext{
${ }^{1}$ The author or the source (S) communicates the message (M1) to the source text reader or the receptor 1 (R1), the translator, who is both the receptor (R) and the source (S) reproduces (translates) the message (M2) for the target text reader or the receptor 2 (R2) and the translation critic or the scholarly judge of translation who is qualified as both the receptor (R) and the source (S) compares the messages (M1 and M2) and judges whether M2is "faithful" to M1. (Kim 2015:62).
} 
The presence of constant underlying Yoruba interference in the translation implies that the source has two messages instead of the expected conventional one message. The first message comes through English, the major language of the text. This is represented as M1 in Nida's framework. Uffelmann's German translation was made from the M1 (English). In additional to the M1 (English), there exists another message channel associated with the underlying Yoruba background of the author. This channel generates the stylistic code mixings and transliterations. This message is not accounted for in Nida's framework. It is an additional message from the source, so it is $\mathrm{M} 1_{\mathrm{y}}$ (using subscript $y$ because it is channelled in Yoruba. Uffelmann is not aware of the message coded in $\mathrm{M} 1_{\mathrm{y}}$. Therefore, the message sent through code switching, code mixing and transliteration in $\mathrm{M} 1_{\mathrm{y}}$ are not available to the translator who only has access to M1. While Nida's translation critics in the third row have access the R1 (Receptor of M1), they cannot assess the Yoruba message sent through code mixing and transliteration in $\mathrm{M} 1_{\mathrm{y}}$ because they are only available to the translator $\mathrm{R} 1_{\mathrm{y}}$ (the Receptor of the Yoruba message, $\mathrm{M} 1_{\mathrm{y}}$ ). The current analysis links the $\mathrm{M} 1_{\mathrm{y}}$ with the translation critics in the third row to derive the framework in (12).

The interference from Yoruba in the translation of the text to German, makes it necessary to revise Nida's proposal. In this way, the source does not just produce a single message M1, it also produces an underlying message from the interfering mother tongue of the author. This we call $\mathrm{M} 1_{\mathrm{u}}$. While the $\mathrm{M} 1$ is linked with the first receptor $\mathrm{R} 1, \mathrm{M} 1_{\mathrm{u}}$ is linked to its own receptor $\mathrm{R} 1_{\mathrm{u}}$.

\section{Conclusion}

In order to express the African thoughts and culture, African writers are bound to make use of at least two languages at a time - their mother tongue and the colonial language. Therefore, the problem is that the translation is not merely English to German, it also involves Yoruba and Pidgin, with the former playing vital roles such as code switching, code mixing and transliteration. While Uffelmann could translate the Pidgin, he could not take care of the Yoruba data in the text.

While literal approach to free translation usually holds where doubts arises, it also requires the translator to be able to play the role of the original author (Nabokov, 1941; 2011; Rothermel, 2014)). To be faithful to the original works goes beyond the general language perception but rather the author's intention. If the author were to read the translated work, will it still look original? Will the author still be happy that the readers of the translation can access the message in the original work? Although Soyinka's Aké was written in English, Uffelmann's translation may not represent the full intent of the author part of which were encoded in Yoruba, the author's mother tongue.

For the fact that euro phone African literature may reflects much of the linguistic background of the author in the source text, the acceptable translation of such text like Aké, Years of Childhood will require a translator critic who knows the source language and ultimately the author's linguistic style. The peculiar linguistic features that are painted with African undertones and allusions in the text, make the translation complex for the Europeans and non-African readers, who are professional but incompetent in the multilingual background of the source text, to successfully translate.

\section{References}

Baker, M. (1992).In Other Words: A Course book on Translation. London and New York: Routledege. Bassnett, S. (1992).Translation Studies. London: Routledge.

Broeck, R. van den. (1978). The concept of equivalence in translation theory. Some critical reflections. In Holmes, J.S.,Lambert, J. and Broeck, R. van den (eds.) Literature and Translation. Leuven: Academic, 947.

Catford, J.C. (1965). A Linguistic Theory of Translation. London: Oxford University Press.

Daghoughi S. \& Hashemian M. (2016). "Analysis of Culture-Specific Items and Translation Strategies Applied in Translating Jalal Al-Ahmad's by the Pen" In: English Language Teaching: Vol. 9, No. 4. 171-185.

Iran: Canadian Center for Science and Education Duranti, A. (1997). Linguistic Anthropology. Cambridge: Cambridge University Press.

Durdureanu, I. I. (2011). “Translation of Cultural Terms: Possible or Impossible?” In: Journal of Linguistic and Intercultural education, Vol. 4, 51-63.

House, J. (1997). Translation Quality Assessment: A Model Revisited. Tübingen: Narr.

Jakobson, R. (1959/2000). On linguistics aspects of translation. In Venuti, L. (ed.) (2000), The Translation Studies Reader. London and New York: Routledge, 113-118. 
Kim, D. (2015). Dynamic equivalence: Nida's perspective and beyond. Semantic ScholarAvailable at https://pdfs.semanticscholar.org>cda4Retrieved on April23, 2018.

Koller, W. (1979). Einführung in die Übersetzungswissenschaft. Heidelberg: Quelle and Meyer.

Koller, W. (2011). Einführung in die Übersetzungswissenschaft. Tübingen: Francke.

Lambert, J. (1998). "Literary Translation"In: M. Baker, ed. Routledge Encyclopedia of Translation Studies. London: Routledge, 130-134.

Lefevere, A. (1993). Translating Literature: Practice and Theory in a Comparative Literature Context. New York: The Modern Language Association of America.

Mailhac, Jean-Pierre (1996). "Evaluating Criteria for the Translation of Cultural References", in: On Translating French Literature and Film, edited by Geoffrey Harris (Amsterdam, Rodopi), pp. 177-188.

Munday, J. (2000). Introducing Translation Studies. London and New York: Routledge.

Nabokov, V. (1941). The Art of Translation. Available at: http:// www.newrepublic.com/article/books-ndarts/theart-translation. Retrieved on April23, 2018.

Nabokov, V. (1990). Eugene Onegin. A Translation from the Russian of Aleksander Pushkin's Yevgeniy Onegin. Princeton: Princeton University Press.

Nabokov, V. (2011). Strong Opinions. London: Penguin Classics.

Newmark, P. (1981). Approaches to translation. Oxford: Pergamon Press.

Newmark, P. (1998).More Paragraphs on Translation. New York: Prentice Hall.

Nida, E.A. (1964). Towards a Science of Translation. Leiden: E.J. Brill.

Nida, E.A., \& Taber, C.R. (1969). The Theory and Practice of Translation. Leiden: E.J. Brill

Nida, E. (1969). Science of translation. Language 45, 483-498.

Nord, C. (1991). Text Analysis in Translation. Amsterdam: Rodopi.

Nord, C. (1997). Translating as a Purposeful Activity: Functionalist Approaches Explained. Manchester: St. Jerome.

Olagunju, E. O. (2003). "Pidginisation and Creolisation: A Study of Nigerian Pidgin”.In: Ife Journal of Foreign languages. No. 5, 46-52

Pym, A. (1998). Method in Translation History. Manchester: St Jerome.

Pym, A. (2010). Exploring Translation Theories. London and New York: Routledge.

Reiss, K. (2000). Translation criticism - The potentials and limitations. Categories and criteria for translation quality assessment. Manchester: St. Jerome Publishing.

Rothermel,P. (2014). Vladmir Nabokov: a case study of Multilingualism and Translation. Style of Communication. 6 (1): 130-138.

Soyinka, Wole (1981). Aké, Years of Childhood, Ibadan: Spectrum Books.

Soyinka, Wole (1986). Aké, Jahre der Kindheit, (übers. Von Inge Uffelmann), Zürich: Ammann Verlag.

Panou, D. (2013) Equivalence in translation theories: a critical evaluation. Theory and Practice in Language Studies, 3:(1): 1-6,

Venuti, L. (1998). Strategies of translation. In M. Baker (Ed.), Encyclopedia of translation studies (pp. 240-244). London and New York: Routledge.

Vinay, J.P. and Darbelnet, J. (1958). Stylistique Comparée du Francais et de l' Anglais: Méthode deTraduction. Paris:Didier.(Transl. and ed. by Sager, J.C. and Hamel, M.J. (1995) as Comparative Stylistics of French and English: A Methodology for Translation. Amsterdam and Philadephia: John Benjamins.) 

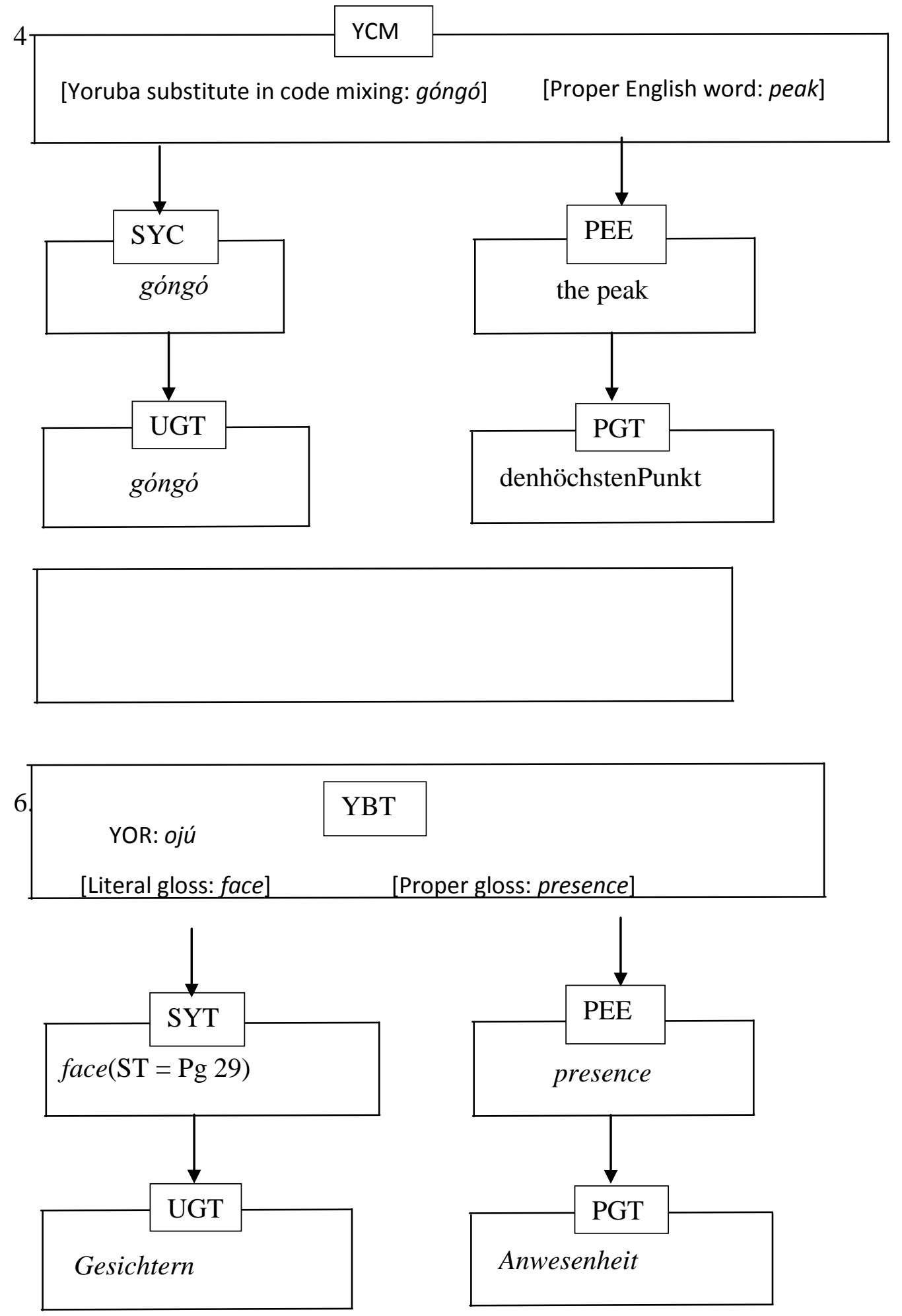
8.

YOR: bailẹ jẹ

\section{YBT}

[Literal gloss: to spoil the ground]

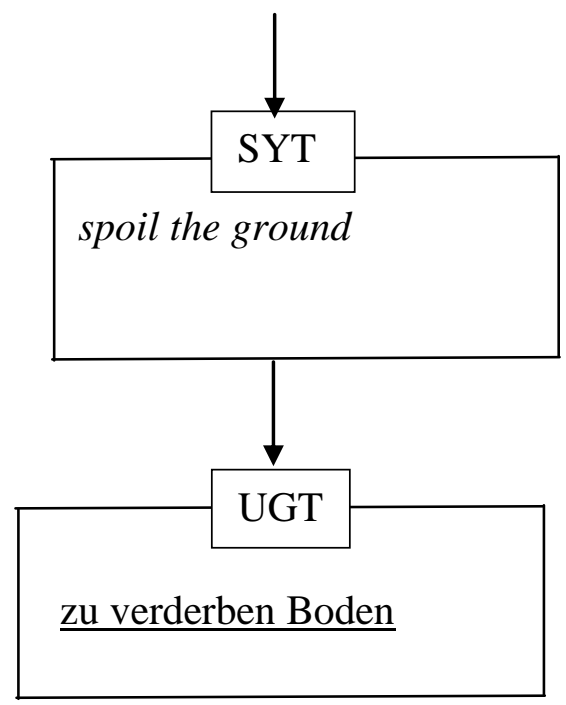

[Proper gloss: to worsen]

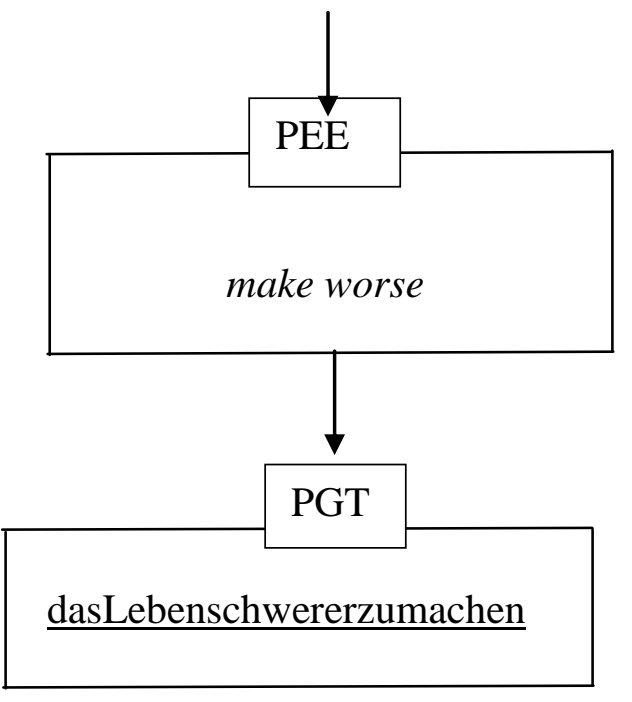

10.

YO: ...òdoolójú eja.

YBT

[Literal gloss: null like fish eye]

[Proper gloss: null]

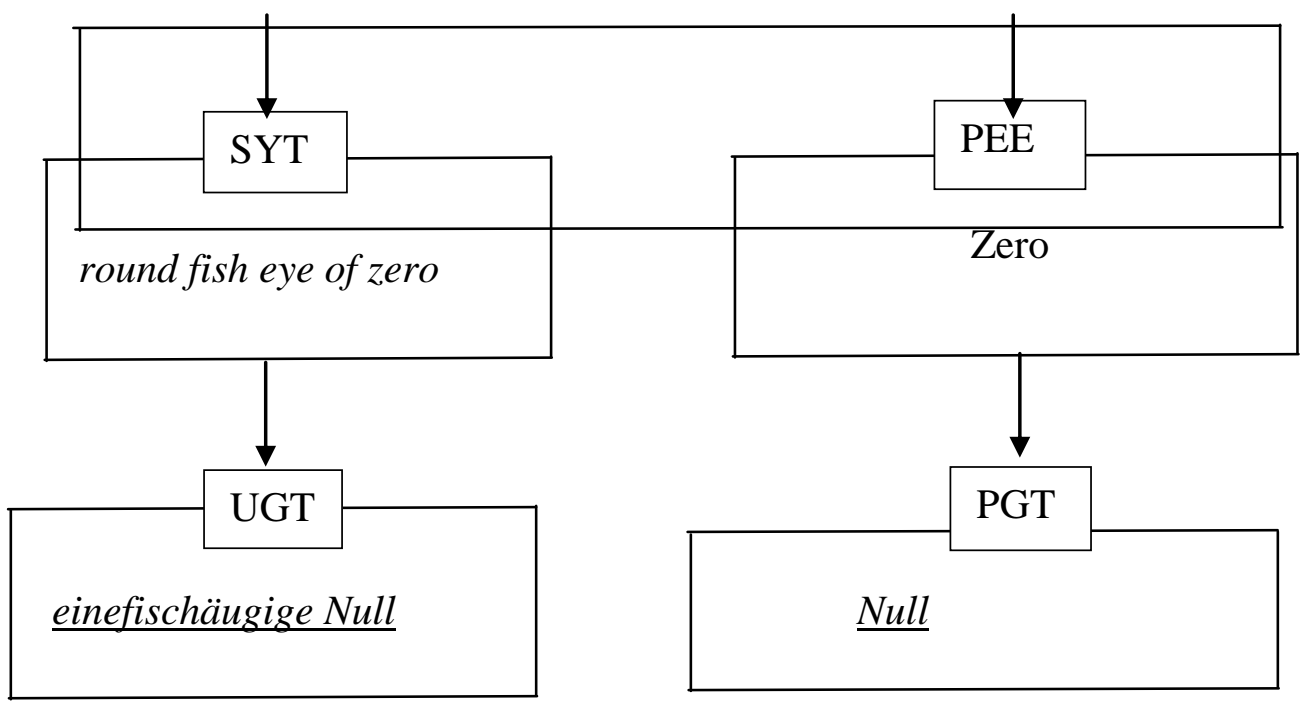


11.
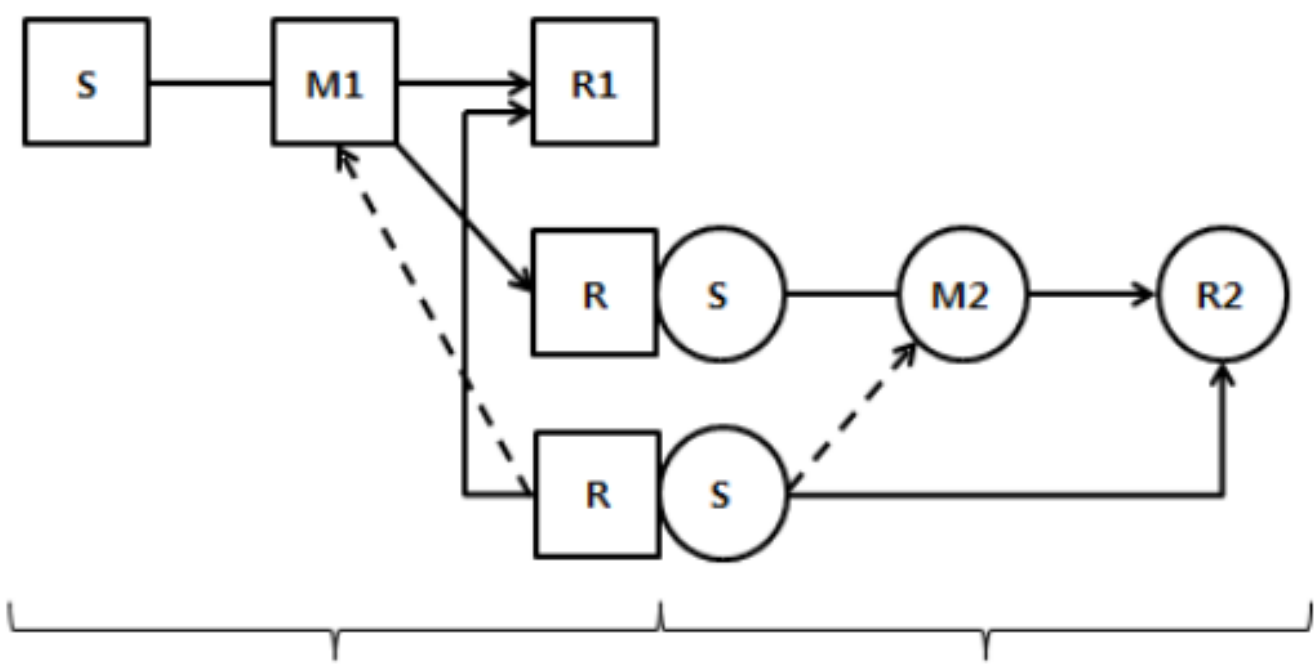

Source

Receptor

Language

Language

(Nida, 1969: 23; Kim, 2015:62)

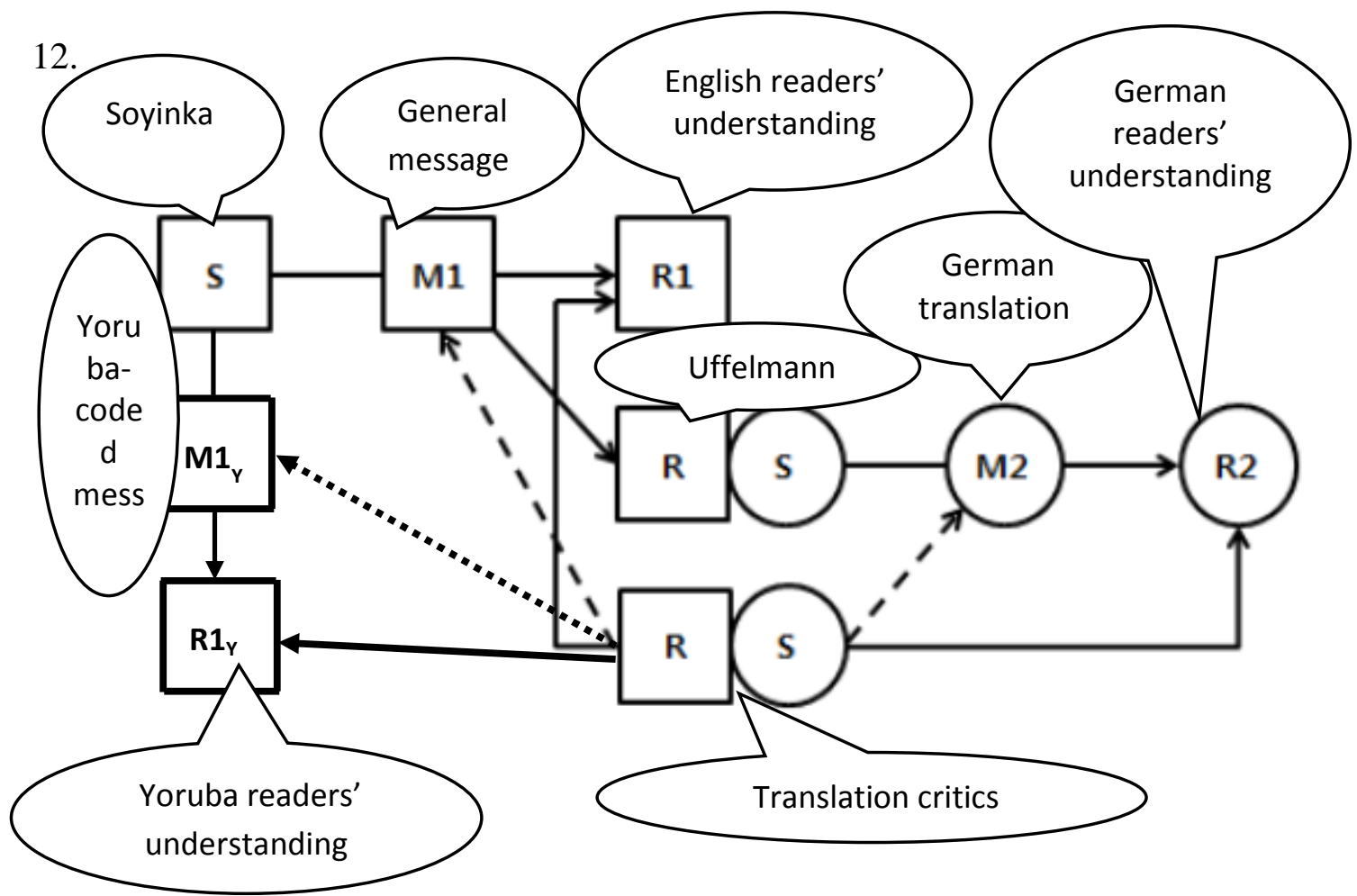


13

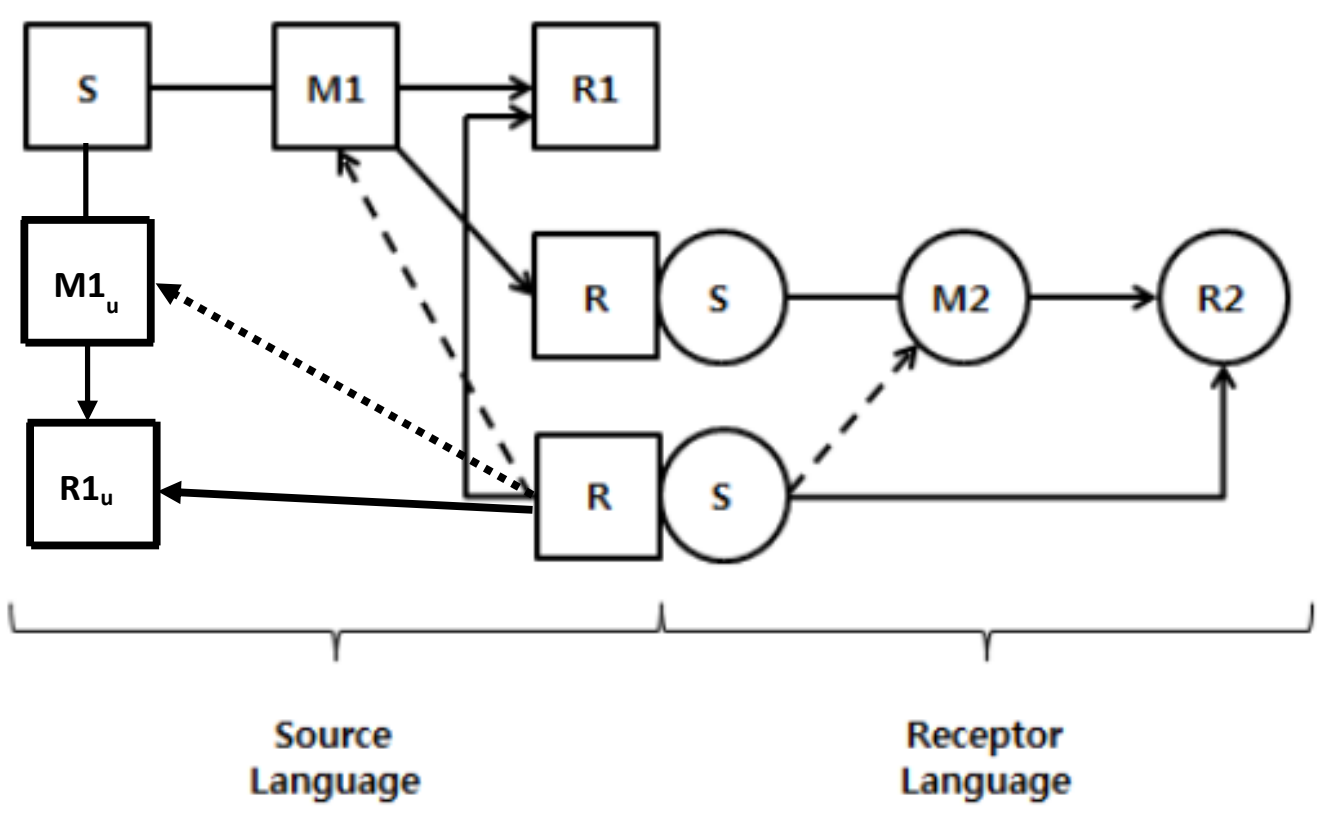

